\title{
Labour-associated changes in the regulation of production of immunomodulators in human amnion by glucocorticoids, bacterial lipopolysaccharide and pro-inflammatory cytokines
}

\author{
K. L. Simpson, J. A. Keelan* and M. D. Mitchell \\ Department of Pharmacology and Clinical Pharmacology, University of Auckland School of Medicine, Private Bag 92109, \\ Auckland, New Zealand
}

\begin{abstract}
Parturition is associated with changes in the production of inflammatory mediators by gestational tissues. An explant system was established to study the change in response of human amnion to various regulating factors during labour. Disks of tissue $(6 \mathrm{~mm})$ were excised from amnion membranes obtained either at term by Caesarian section before labour $(n=5-6)$ or after spontaneous vaginal delivery $(n=3-7)$. After $24 \mathrm{~h}$ equilibration in media, the tissues were treated with interleukin $1 \beta\left(10 \mathrm{ng} \mathrm{ml}^{-1}\right)$, tumour necrosis factor $\alpha\left(100 \mathrm{ng} \mathrm{ml}^{-1}\right)$, lipopolysaccharide $\left(5 \mu \mathrm{g} \mathrm{ml}^{-1}\right)$ and dexamethasone $\left(1 \mu \mathrm{mol} \mathrm{l}^{-1}\right)$ or an appropriate vehicle control for $24 \mathrm{~h}$ ( $n=3$ wells per treatment). Media were harvested and interleukin 10, interleukin 6 and prostaglandin $\mathrm{E}_{2}$ concentrations were determined by immunoassay. In tissues taken both before and after the onset of labour, basal interleukin 10 production by amnion explants was near to the limit of detection. Basal production rates of $\mathrm{PGE}_{2}$ by amnion explants were significantly higher $(P<0.0012$; Mann-Whitney $U$ test) in tissues taken during labour than in tissues taken before the onset of labour, while interleukin 6 production was not significantly altered by labour. Production rates of interleukin 6 and prostaglandin $E_{2}$ were significantly increased by interleukin $1 \beta$, tumour necrosis factor $\alpha$ and lipopolysaccharide in explants from tissues taken during and before labour, while the responsiveness of interleukin 10 production to these treatments was inconsistent. Dexamethasone had no effect on interleukin 6 production by amnion explants, but significantly inhibited prostaglandin $\mathrm{E}_{2}$ production, although this inhibition was approximately $30 \%$ lower in tissues obtained after the onset of labour. These results support the presence of inflammatory positive feedback cycles, coincident with a deficiency of an anti-inflammatory factor within gestational tissue, which may be involved in the progression or maintenance of labour.
\end{abstract}

\section{Introduction}

Amniotic fluid contains detectable quantities of a variety of immunomodulatory factors. These include proinflammatory cytokines (for example, interleukin $1 \beta$ (IL-1 $\beta$ ), tumour necrosis factor $\alpha$ (TNF- $\alpha$ ), IL- 6 and IL- 8 ) and derivatives of arachidonic acid metabolism, such as prostaglandins (PGs). The concentrations of these substances in amniotic fluid increase with labour at term, and preterm in the presence of intrauterine infection (Hillier et al., 1990; Romero et al., 1991, 1992, 1994, 1996; Laham et al., 1993; Opsjon et al., 1993; Halgunset et al., 1994; Stallmach et al., 1995; Gomez et al., 1997). Indeed, the increased concentration of cytokines, particularly of IL-6, in the amniotic fluid may be of use as a diagnostic indicator for intrauterine infectionassociated preterm labour and delivery (Dudley et al., 1994a; Andrews et al., 1995).

${ }^{*}$ Correspondence.

Received 10 September 1998.
In addition to these pro-inflammatory mediators, antiinflammatory cytokines, such as IL-10, have also been measured in human amniotic fluid during late gestation (Heyborne et al., 1994; Greig et al., 1995; Dudley et al., 1997a). Interleukin 10 is produced by $\mathrm{T}$ cells, $\mathrm{B}$ cells, macrophages and cells of human chorion, decidual and placental tissues (Howard and O'Garra, 1992; Moore et al., 1993; Mosmann, 1994; Cadet et al., 1995; Roth et al., 1996; Dudley et al., 1997b; Jones et al., 1997; Paradowska et al., 1997; Trautman et al., 1997). Interleukin 10 displays predominantly inhibitory effects on cell-mediated inflammatory reactions throughout the body (Howard and O'Garra, 1992). With respect to the tissues of pregnancy, cytokine and prostaglandin production by human chorion, decidual and placental cells in culture are inhibited by IL-10 (Dudley et al., 1994b, 1996b; Spencer et al., 1995; Fortunato et al., 1996, 1997; Keelan and Mitchell, 1996; Trautman et al., 1996; Goodwin et al., 1998).

Human amnion synthesises and releases IL-6, IL-8 and $\mathrm{PGE}_{2}$, both basally and in response to inflammatory stimuli and bacterial products (Casey and MacDonald, 1993; Dudley 
and Trautman, 1994; Kelly, 1994; Mitchell et al., 1995; De Jongh et al., 1996; Dudley et al., 1996a; Laham et al., 1996; Petraglia et al., 1996; Gomez et al., 1997; Keelan et al., 1997). It has been reported that amnion cells in monolayer culture express only a very weak mRNA signal for IL-10 and do not secrete detectable quantities of IL-10 protein (Trautman ef al., 1997). Although the glucocorticoid agonist, dexamethasone, has been shown to inhibit IL-6 and IL-8 release from amnion epithelial cells and fibroblasts in culture (Keelan et al., 1997), $\mathrm{PGE}_{2}$ production by amnion cells in culture can be either inhibited or stimulated by dexamethasone, an effect attributed to the outgrowth of amnion-derived fibroblasts in vitro (Mitchell et al., 1988; Potestio et al., 1988; Gibb and Breton, 1993; Economopoulos et al., 1996). The net effect of these opposing actions by glucocorticoids on amnion prostaglandin production has yet to be clarified.

The importance of inflammatory processes in labour has been postulated for some time (Opsjon et al., 1993; Halgunset et al., 1994; Kelly, 1994; Romero et al., 1994, 1996; Dudley et al., 1996a). The present study was designed to test the hypothesis that an increase in responsiveness to proinflammatory signals, and a decrease in anti-inflammatory responses, accompanies normal parturition. The importance of the amnion in the maintenance of pregnancy and the onset of parturition was the reason for it being selected for study. An amnion tissue explant system was used to maintain tissue integrity and to eliminate changes associated with cell dispersion for culture, thus reproducing in vivo responses more closely. Interleukin 6, IL-10 and $\mathrm{PGE}_{2}$ production were selected for measurement since they are both representative of immunoregulators present in amniotic fluid and because of their known relevance to parturition.

\section{Materials and Methods}

\section{Materials}

Culture medium (Hams F12/DMEM) was obtained from Irvine Scientific (Santa Ana, CA). Fetal calf serum (FCS) was purchased from Life Technologies Ltd (Auckland). Bovinegamma globulin (BGG) was purchased from Sigma Chemical Corporation (St Louis, MO). Human IL-1 $\beta$ was obtained from the Immunex Corporation, (Seattle, WA). Human TNF- $\alpha$ was provided by J. Fraser (University of Auckland, Auckland). Lipopolysaccharide (LPS) and dexamethasone were obtained from Sigma Chemical Corporation. Recombinant human IL6, anti-IL-6 antisera and human recombinant IL-10 were obtained from R and D Laboratories (Minneapolis, MN), and anti-IL-10 antisera were purchased from Pharmingen (San Diego, CA). The streptavidin-alkaline phosphatase was obtained from GIBCO Life Technologies (Auckland), and the phosphatase substrate ( $p$-nitrophenol phosphate) was obtained from Sigma Chemical Corporation. Tritiated PGE for radioimmunoassay was purchased from Amersham plc, (Amersham, Bucks) and non-radiolabelled $\mathrm{PGE}_{2}$ was obtained from Cayman Chemicals (Ann Arbo, MI). Easiwash 96-well ELISA plates were obtained from Corning (New York), while all other disposable tissue culture plasticware was from Nunc (Roskilde).

\section{Explant culture}

Human term placentae were obtained with informed maternal consent, and prior approval from the Auckland Healthcare Human Ethics Committee, from the National Women's Hospital, Auckland, New Zealand. Tissues were obtained from women at term, either by elective Caesarian section before the onset of labour (not in labour, NL) or after uncomplicated spontaneous vaginal delivery (spontaneous labour, SL). The amnion, identified as the inner, avascular membrane, was peeled from the attached choriodecidua membranes and washed in Hams F12-Dulbecco's modified Eagle's medium (DMEM) to remove residual red blood cells. Disks of tissue $(6 \mathrm{~mm})$ were excised using a sterile cork borer, transferred to six-well culture plates (six disks per well, three wells per treatment) and equilibrated for $24 \mathrm{~h}$ in Hams F12-DMEM supplemented with 10\% FCS and antibiotics (Keelan et al. 1997 ) at $37^{\circ} \mathrm{C}$ in a humidified atmosphere of $5 \%$ $\mathrm{CO}_{2}-95 \%$ air. Each of the six disks in a single well was cut from random areas of the membranes to minimize the effects of any regional differences in cytokine production present in these tissues. The mean \pm SD wet mass of tissue per well was $52.8 \pm 22.2 \mathrm{mg}$. After equilibration, media were replaced with serum-free media containing $0.1 \%$ BGG and antibiotics and the following treatments, or appropriate vehicle controls, were added: IL-1 $\beta\left(10 \mathrm{ng} \mathrm{m}^{-1}\right)$, TNF- $\alpha\left(100 \mathrm{ng} \mathrm{ml}^{-1}\right)$, LPS $\left(5 \mu \mathrm{g} \mathrm{ml}^{-1}\right)$ and dexamethasone $\left(1 \mu \mathrm{mol} \mathrm{l}{ }^{-1}\right.$, in ethanol vehicle). After $24 \mathrm{~h}$, the incubation was terminated and the media were stored at $4^{\circ} \mathrm{C}$ before immunoassay. Production rates were normalized to the wet mass of tissue in each well.

\section{Cytokine immunoassays}

Interleukin 10 and IL- 6 were measured by enzyme-linked immunosorbent assays (ELISA). The ELISA for IL-6 was performed as described by Keelan et al. (1997). The assay was performed with a sensitivity of approximately $20 \mathrm{pg} \mathrm{m}^{-1}$ and an intra-assay precision of $5.5 \%$. Interassay precision was $16.1 \%$. The IL-10 ELISA used a monoclonal anti-human IL-10 capture antibody combined with a biotinylated rat anti-human IL-10 detection antibody. The signal was quantitated using streptavidin-alkaline phosphatase with $p$ nitrophenol phosphate. The standard curve for the IL-10 assay ranged from 0 to $2500 \mathrm{pg} \mathrm{ml}^{-1}$. The assay performed with a sensitivity of about $15 \mathrm{pg} \mathrm{ml}^{-1}$ and an intra-assay precision of $2.6 \%$. Interassay precision was $11.2 \%$.

\section{Prostaglandin $E_{z}$ immunoassay}

Media were assayed for $\mathrm{PGE}_{2}$ by a direct radioimmunoassay similar to that described by LundinSchiller and Mitchell et al. (1991), with the exception that the antiserum used was raised in house in rabbits against $\mathrm{PGE}_{2}-\mathrm{BSA}$ and BSA-thyroglobulin conjugates. Media samples or standards prepared in media $(100 \mu \mathrm{l})$ were incubated overnight with [ $\left.{ }^{3} \mathrm{H}\right] \mathrm{PGE}_{2}$ tracer (about 5000 c.p.m. per tube) and antisera (sufficient to give approximately $25 \% B_{0}$ ) at $4^{\circ} \mathrm{C}$. Unbound tracer was removed with cold dextran-coated charcoal, and the radioactivity in the 
supernatant (bound fraction) was determined in a scintillation counter. Curve fitting and data extrapolation were performed using Ultraterm II software (Wallac Oy, Finland). No significant crossreaction $(<0.02 \%)$ of the antiserum was detected with the following eicosanoids: $\mathrm{PGF}_{2 \alpha^{\prime}}$ 6-keto-PGF ${ }_{1 \alpha^{\prime}} \quad \mathrm{PGA}_{2^{\prime}}$ thromboxane $\mathrm{B}_{2}$, 5hydroxyeicosatetraenoic acid (HETE), 12-HETE, 15-HETE, leukotriene $\mathrm{B}_{4}\left(\mathrm{LTB}_{4}\right), \mathrm{LTC}_{4}$, and arachidonic acid. None of the cytokines used in this study crossreacted in the assay. The assay sensitivity was approximately $5 \mathrm{pg} \mathrm{ml}^{-1}$, intra- and interassay precision were 5.6 and $17.8 \%$, respectively.

\section{Statistical analysis}

Prostaglandin and cytokine production rates are expressed as either pg $\mathrm{mg}^{-1}$ wet mass of tissue per $24 \mathrm{~h}$ (median) or as percentage of control values (mean \pm SEM). Values were derived from pooled data from experiments performed on triplicate samples from 3-7 separate placentae. Differences between basal production rates from tissues taken before and after labour onset, and the effects of the various treatments, were tested for statistical difference using the Mann-Whitney $U$ test for non-parametric data. $P<0.05$ was considered significant.

\section{Results}

\section{Basal production of $I L-6, I L-10$ and $P G E$, by amnion explants before and after labour}

Basal production rates of $\mathrm{PGE}_{2}$ by amnion explants were significantly higher $(P<0.0012)$ in tissue taken after labour than in tissue taken before labour (median $=2810$ versus $809 \mathrm{pg} \mathrm{mg}^{-1}$ tissue per 24 h; Fig. 1). However, there was only a slight and not statistically significant increase in median IL-6 production with labour (median $=137$ versus $106 \mathrm{pg} \mathrm{mg}^{-1}$ tissue per $24 \mathrm{~h}$ ).

Basal IL-10 production by amnion explants was near to the limit of detection in all tissues (Fig. 1). Two of the six NL placentae produced a small amount of IL-10 $\left(<1.4 \mathrm{pg} \mathrm{mg}^{-1}\right.$ tissue per $24 \mathrm{~h}$ ), while production rates from all of the SL placentae were below detection limits. There was no significant difference between IL-10 production rates before and after labour (median $=0.25$ and $0.19 \mathrm{pg} \mathrm{mg}^{-1}$ tissue per $24 \mathrm{~h}$, respectively).

\section{Regulation of IL-6, IL-10 and PGE, production by inflammatory mediators before and after labour}

Interleukin 6 production from tissues taken both before and after labour showed a 3-7-fold increase relative to controls in response to IL-1 $\beta$ (10 $\left.\mathrm{ng} \mathrm{ml}^{-1}\right)$ and an approximate twofold increase in response to $\mathrm{TNF}-\alpha\left(100 \mathrm{ng} \mathrm{ml}^{-1}\right)$ (Fig. 2). There were no significant changes in IL-6 production in response to LPS from tissues taken before labour whereas, in tissues taken after labour, LPS did induce a significant increase in IL-6 production to approximately 3.5 -fold of control production. In absolute terms, IL- 6 production rates in response to IL- $1 \beta$ and TNF- $\alpha$ were similar in tissues taken before and after labour, while median IL-6 production in response to LPS was significantly greater in tissues taken after labour (Table 1).

The responsiveness of $\mathrm{IL}-10$ production by amnion explants was inconsistent. In general, IL-10 production remained below detection limits but, occasionally, a small response was evident. In the two NL placentae that had detectable basal IL-10 production rates, production of IL-10 was stimulated by IL-1 $\beta$ (2-25-fold), TNF- $\alpha$ (3-16-fold) and LPS (approximately fivefold). Interleukin 10 production rates from the other four placentae remained below detection

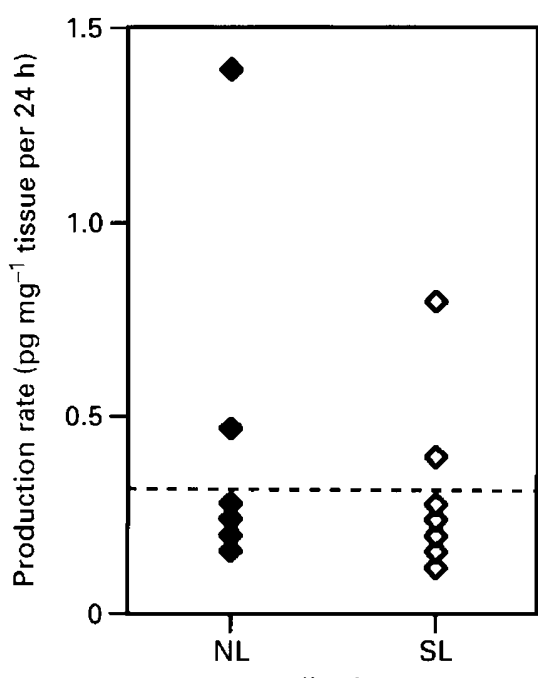

IL-10

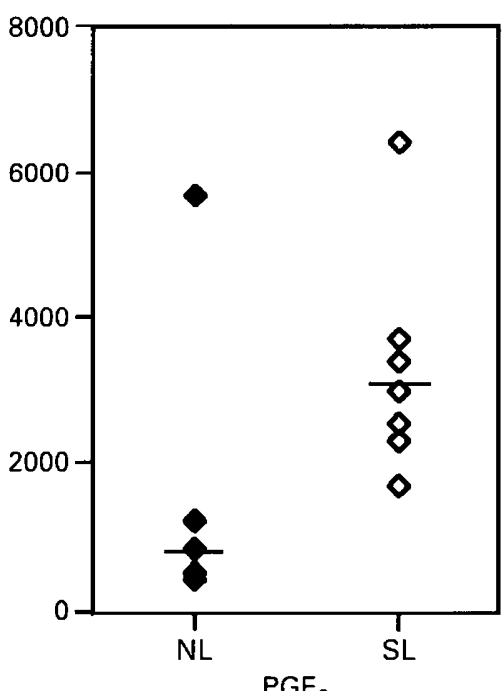

$\mathrm{PGE}_{2}$

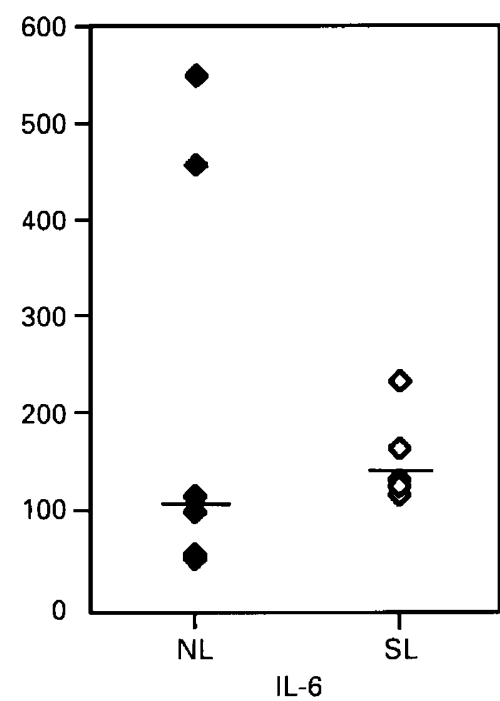

IL-6

Fig. 1. Basal production of interleukin 10 (IL-10), prostaglandin $E_{2}\left(P_{G}\right.$ ) and IL-6 by explants of amnion tissues taken before $(\mathrm{NL} ; n=6)$ and after (SL; $n=7$ ) labour. All points below the dashed line were below the limit of detection for the IL-10 assay. Horizontal bars represent the medians (median IL-10 production was below the limit of detection). There was a significant increase in $\mathrm{PGE}_{2}$ production after labour $(P<0.001)$; however, there were no significant differences between IL-10 and IL-6 production rates by tissues taken before or after labour. Results were analysed by Mann-Whitney U test for non-parametric data. 
Table 1. Effects of inflammatory mediators on production of interleukin 6 (IL-6) and prostaglandin $\mathrm{E}_{2}\left(\mathrm{PGE}_{2}\right)$ by amnion explants

\begin{tabular}{llcccc}
\hline & \multicolumn{4}{c}{ Treatment } \\
\cline { 3 - 6 } & & Control & IL-1 $\beta\left(10 \mathrm{ng} \mathrm{ml}^{-1}\right)$ & TNF- $\alpha\left(100 \mathrm{ng} \mathrm{ml}^{-1}\right)$ & LPS $\left(5 \mu \mathrm{g} \mathrm{ml}^{-1}\right)$ \\
\hline $\mathrm{IL}-6$ & $\mathrm{NL}$ & $106(13-715)$ & $371(35-2330)$ & $217(23-2535)$ & $162(66-612)$ \\
& $\mathrm{SL}$ & $138(108-333)$ & $470(242-2294)$ & $251(194-357)$ & $488(174-1190)^{*}$ \\
$\mathrm{PGE}_{2}$ & $\mathrm{NL}$ & $809(241-7991)$ & $4222(355-14173)$ & $2382(330-9547)$ & $1040(247-3805)$ \\
& $\mathrm{SL}$ & $2810(1346-10931)^{*}$ & $6802(2663-14285)^{*}$ & $7619(4747-9208)^{*}$ & $4176(2083-15145)^{*}$ \\
\hline
\end{tabular}

Data represented as median (range). ${ }^{*} P<0.05$ versus NL by Mann-Whitney $U$ test.

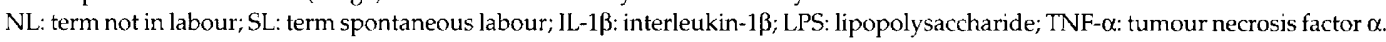

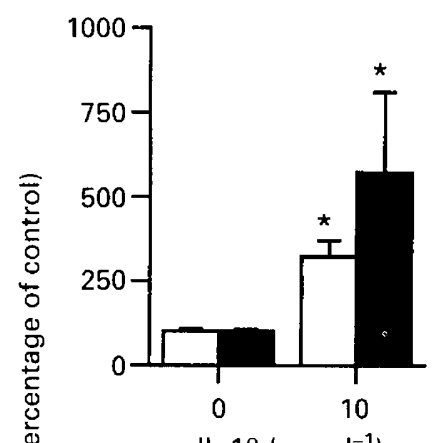

$\mathrm{IL}-1 \beta$ (ng ml $\mathrm{m}^{-1}$ )

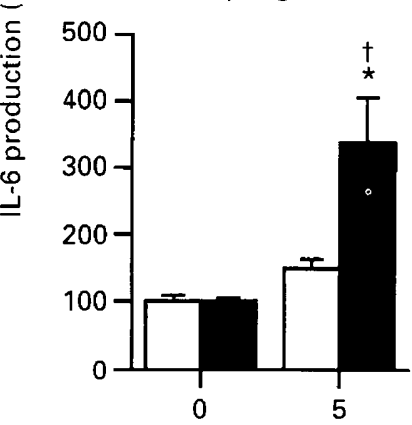

LPS $\left(\mu \mathrm{g} \mathrm{ml}^{-1}\right)$

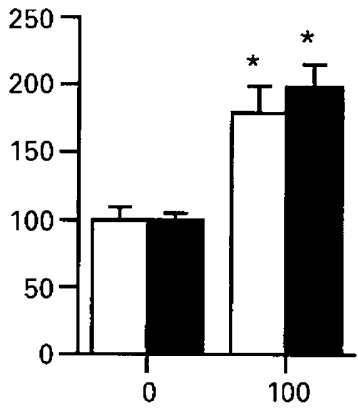

TNF- $\alpha\left\{\mathrm{ng} \mathrm{ml}^{-1}\right.$ )

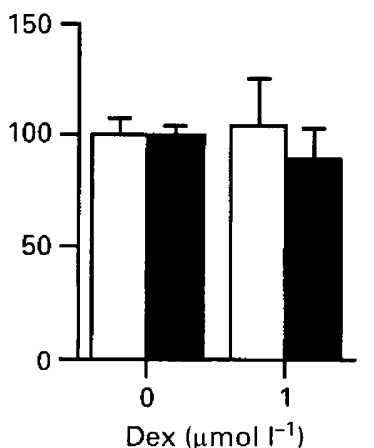

Fig. 2. Interleukin 6 (IL-6) production by amnion explants in response to treatment with IL-1 $\beta$, tumour necrosis factor $\alpha$ (TNF- $\alpha$ ), lipopolysaccharide (LPS) and dexamethasone (Dex) over $24 \mathrm{~h} . \square$, Tissues taken before labour (NL; $n=5-6)$; $\boldsymbol{n}$, tissues taken after labour (SL; $n=3-7)$. Production is expressed as a percentage of the control (mean \pm SEM). ${ }^{*} P<0.05$ from control; ${ }^{+} P<0.05$ from NL (Mann-Whitney U test).

limits (data not shown). Only one of the SL placentae responded to IL-1 $\beta$ by producing detectable amounts of IL$10\left(4.6 \pm 0.65 \mathrm{pg} \mathrm{mg}^{-1}\right.$ tissue per $\left.24 \mathrm{~h}\right)$. In contrast, four produced detectable amounts of IL-10 in response to LPS $\left(3.2 \pm 2.0 \mathrm{pg} \mathrm{mg}^{-1}\right.$ tissue $24 \mathrm{~h}$ ) (data not shown).

IL-1 $\beta\left(10 \mathrm{ng} \mathrm{ml}^{-1}\right)$, TNF- $\alpha\left(100 \mathrm{ng} \mathrm{ml}^{-1}\right)$ and LPS $\left(5 \mu \mathrm{g} \mathrm{ml}^{-1}\right)$ induced significant increases $(P<0.05)$ in $\mathrm{PGE}_{2}$ production from tissues taken both before and after labour. The responsiveness of $\mathrm{PGE}_{2}$ production to TNF- $\alpha$ (a 2-2.5-fold increase relative to control) and to LPS (an approximate 1.5fold increase relative to controls) was similar in tissues taken before and after labour. However, the responsiveness to IL-1 $\beta$ was significantly reduced from an approximate 4.5-
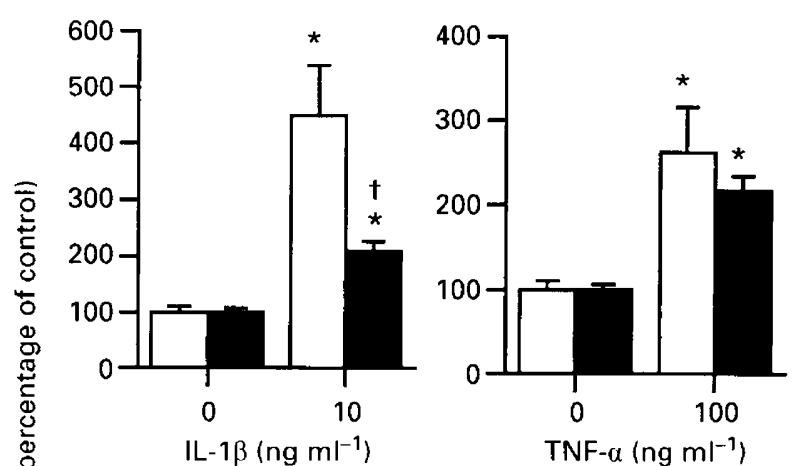

IL-1 $\beta$ (ng ml-1)

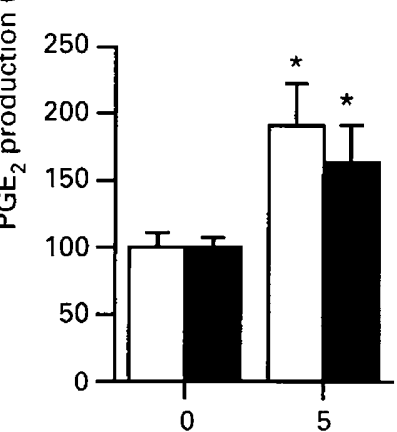

LPS $\left(\mu \mathrm{g} \mathrm{ml}^{-1}\right)$

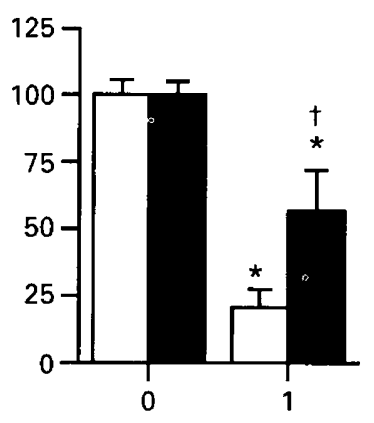

$\operatorname{Dex}\left(\mu \mathrm{mol} \mathrm{I}^{-1}\right)$
Fig. 3. Prostaglandin $E_{2}\left(P E_{2}\right)$ production by amnion explants in response to treatment with interleukin $1 \beta$ (IL-1 $)$, tumour necrosis factor $\alpha$ (TNF- $\alpha$ ), lipopolysaccharide (LPS) and dexamethasone (Dex) over 24 h. $\square$, Tissues taken before labour (NL; $n=5-6$ ); $\mathbf{\square}$, tissues taken after labour (SL; $n=3-7)$. Production is expressed as a percentage of the control (mean \pm SEM). ${ }^{*} P<0.05$ from control; ${ }^{+} P<0.05$ from NL (Mann-Whitney U test).

fold to an approximate twofold increase relative to controls after labour. The mean absolute production of $\mathrm{PGE}_{2}$ from tissues obtained after labour in response to all treatments was significantly higher than production from tissues taken before labour (Table 1).

\section{Regulation of IL-10, IL-6 and PGE, production by dexamethasone}

None of the tissues treated with dexamethasone produced detectable quantities of IL-10. Interleukin 6 production by 
amnion explants was not significantly affected by dexamethasone in tissues taken either before or after labour. Conversely, dexamethasone significantly inhibited $\mathrm{PGE}_{2}$ production in both cases. However, this inhibition was significantly attenuated in tissues obtained after labour compared with tissues taken before labour (approximately $45 \%$ versus approximately $75 \%$ inhibition).

\section{Discussion}

There is abundant evidence that normal term labour and delivery are associated with the activation of inflammatory processes in the fetal membranes, decidua and cervix. The aim of the present study was to establish whether amnion tissue undergoes altered sensitivity to pro- and antiinflammatory regulators during labour, with respect to the secretion of immunomodulators. It was hypothesized that not only would production of inflammatory substances increase after labour, but also production would be more responsive to inflammatory signals and, perhaps, less responsive to anti-inflammatory mediators. The results confirm that $\mathrm{PGE}_{2}$ production by amnion tissues increases markedly with the onset of labour (Olson et al., 1983; Skinner and Challis, 1985; Lopez-Bernal et al., 1987; Mitchell et al., 1995), supporting the validity of the model used and the findings of the present study. However, the finding that there was not a significant increase in IL-6 production with labour is in contrast to the findings of Laham et al. (1996) who reported an 80-fold increase in IL-6 release from amnion explants with the onset of labour. The present experiments were performed after a $24 \mathrm{~h}$ wash-out period to allow recovery of the tissues from the effects of exposure to stimuli associated with delivery, whereas the experiments performed by Laham et al. (1996) were conducted only $1 \mathrm{~h}$ after isolation and processing of the tissue. Hence, a transient increase in cytokine production after processing may have contributed towards their findings.

Interleukin $1 \beta$, TNF- $\alpha$ and LPS all significantly increased amnion $\mathrm{PGE}_{2}$ production in tissues taken both before and after labour, consistent with previous observations (Romero et al., 1988, 1989; Bry and Hallman, 1991; Pollard and Mitchell, 1993; Perkins and Kniss, 1997). In each case, responsiveness (measured as a percentage increase) of $\mathrm{PGE}_{2}$ production was slightly less in tissues taken after labour. However, owing to the large labour-associated increase in $\mathrm{PGE}_{2}$ production, this decreased responsiveness may reflect an attenuated capacity for increased $\mathrm{PGE}_{2}$ production in the tissues taken after labour. Nevertheless, the results provide evidence against a heightened response to inflammatory stimuli during labour. In contrast, although amnion IL-6 production was increased to a similar extent by IL- $1 \beta$ and TNF- $\alpha$ in tissues taken both before and after labour, LPS was only effective in inducing IL6 production in tissues taken after labour. The fact that LPS was able to induce $\mathrm{PGE}_{2}$ production with similar efficiency in both categories of tissue indicates that the LPS receptor is present in the amnion before and after labour. This finding may imply that the link between the LPS receptor and IL-6 production is not functional, or is perhaps blocked, until after labour onset. Alternatively, changes in the cell population of the membranes with labour may explain these observations. Since an increase in basal IL-6 production by tissues taken during labour was not detected in the present study, this increased responsiveness to LPS would seem to be disassociated with a broader increase in sensitivity to inflammatory signals in this tissue. Although some effects of IL- 6 on placental hormone production have been described (Neki et al., 1993; Stephanou and Handwerger, 1994), the role of IL-6 in pregnancy awaits elucidation. Interleukin 6 has been shown to be capable of stimulating prostaglandin production in gestational tissues (Mitchell et al., 1991) but only at very high concentrations. It is possible that IL-6 has currently unrecognized effects on placental or fetal tissues. There are no data on the localization of IL-6 receptors in the gestational membranes.

Dexamethasone significantly inhibited amnion $\mathrm{PGE}_{2}$ production in both tissues taken before and after onset of labour. Production of $\mathrm{PGE}_{2}$ and expression of prostaglandinH-synthase 2 (PGHS-2) by amnion-derived fibroblasts in monolayer culture has been shown to be stimulated by dexamethasone, whereas amnion epithelial cell $\mathrm{PGE}_{2}$ production is inhibited by dexamethasone (Keelan et al., 1997; De Val et al., 1998; Economoupolous et al., 1996). The present results indicate that the net effect of glucocorticoids is a suppression of amnion prostaglandin production, supporting the possibility that the stimulatory effects observed in vitro are an artifact of culture. The inhibitory effect of dexamethasone on PGE, production appears to decrease significantly with labour. Changes in the cell populations within the amnion may explain these findings. Alternatively, there may be a decrease in the sensitivity or responsiveness of the glucocorticoid receptor during labour. However, this seems unlikely since glucocorticoid receptor abundance in gestational membranes is unaffected by labour status (Sun et al., 1996). The lack of effect of dexamethasone on amnion IL-6 production is in contrast to findings in dispersed cell cultures (Keelan et al., 1997), which highlights the potential differences in response characteristics of tissue explants compared with dispersed cells.

Cells typically associated with IL-10 production, such as macrophages, are normally present in low numbers in the amnion mesenchyme (Bulmer and Johnson, 1984). However, IL-10 production by amnion cultures has been reported as unmeasurable, despite low concentrations of IL-10 mRNA expression in this tissue (Trautman et al., 1997). Since conditioned media from tissue explants contains higher concentrations of cytokines than media from dispersed cells in culture, it was hypothesized that amnion explants produce detectable quantities of IL-10. However, in the present study, only a few explants produced detectable amounts of IL-10, which may reflect merely a limitation in assay sensitivity. When it was measurable, IL-10 production was stimulated by IL-1 $\beta$, TNF- $\alpha$ and LPS, which was in agreement with the results of studies on macrophages and monocytes (Mosmann, 1994; Fushimi et al., 1997) and decidual cells in culture (Dudley et al., 1997b; Jones et al., 1997; Paradowska et al., 1997; Trautman et al., 1997). Although production of IL-10 by amnion has been demonstrated, the present results neither prove nor disprove the hypothesis that this tissue is a major contributor to the IL- 
10 in amniotic fluid (Heyborne et al., 1994; Greig et al., 1995; Dudley et al., 1997a). As there are no data on the passage of IL-10 across the membranes, it remains a possibility that amniotic fluid IL-10 originates in the decidua, chorion or placenta, all of which are known to produce this cytokine (Cadet et al., 1995; Bennett et al., 1996; Roth et al., 1996; Dudley et al., 1997b; Jones et al., 1997; Paradowska et al., 1997; Trautman et al., 1997). Kent et al. (1994) reported that there is only limited transfer of the cytokines IL-1 $\alpha$, IL-1 $\beta$, TNF- $\alpha$ and IL- 6 across intact human fetal membranes.

In conclusion, the present findings do not support the presence of an increased responsiveness to inflammatory mediators during labour in human amnion, but do indicate the existence of a labour-associated attenuation of the antiinflammatory effects of glucocorticoids in this tissue. The mechanism behind this change remains to be defined.

\section{References}

Andrews WW, Hauth JC, Goldenberg RL, Gomez R, Romero R and Cassell GH (1995) Amniotic fluid interleukin-6: correlation with upper genital tract microbial colonization and gestational age in women delivered after spontaneous labour versus indicated delivery Anterican Journal of Obstetrics and Gynecology 173 606-612

Bennett WA, Lagoo-Deenadaylalan S, Brackin MN, Hale E and Cowan BD (1996) Cytokine expression by models of human trophoblast as assessed by a semiquantitative reverse transcription-polymerase chain reaction technique American Journal of Reproductive Immunology 36 285-294

Bry K and Hallman M (1991) Synergistic stimulation of amnion cell prostaglandin $E_{2}$ synthesis by interleukin-1, tumor necrosis factor and products from activated human granulocytes Prostaglandins, Leukotrienes and Essential Fatty Acids 44 241-245

Bulmer JN and Johnson PM (1984) Macrophage populations in the human placenta and amniochorion Clinical and Experimental Immunology $57393-403$

Cadet P, Rady PL, Tyring SK, Yandell RB and Hughes TK (1995) Interleukin10 messenger ribonucleic acid in human placenta: implications of a role for interleukin-10 in fetal allograft protection American Journal of Obstetrics and Gynecology 173 25-29

Casey ML and MacDonald PC (1993) Cytokines in the human placenta, fetal membranes, uterine decidua, and amniotic fluid. In Molecular Aspects of Placental and Fetal Membrane Autocoids pp 361-395 Eds GE Rice and SP Brennecke. CRC Press, Boca Raton, FL

De Jongh R, Jorens P, Student I and Heylen R (1996) The contribution of the immune system to parturition Mediators of Inflammation 5 173-182

De Val D, Hansen WR, Keelan JA, Sato TA and Mitchell MD (1998) Dexamethasone differentially regulates prostaglandin $\mathrm{E}_{2}\left(\mathrm{PGE}_{2}\right)$ production in amnion fibroblast and epithelial cells Journal of the Society for Gynecological Investigation $5189 \mathrm{~A}$

Dudley DJ and Trautman MS (1994) Infection, inflammation, and contractions: the role of cytokines in the pathophysiology of preterm labour Seminars in Reproductive Endocrinology 12 263-272

Dudley DJ, Hunter C, Mitchell MD and Varner MW (1994a) Clinical value of amniotic fluid interleukin 6 determinations in the management of preterm labour British Journal of Obstetrics and Gynecology 101 592-597

Dudley DJ, Spencer S, Edwin S and Mitchell MD (1994b) Interleukin 10 inhibits cytokine production by human gestational tissues Cytokine 6545

Dudley DJ, Collmer D, Mitchell MD and Trautman MS (1996a) Inflammatory cytokine mRNA in human gestational tissues: implications for term and preterm labour Journal of the Society for Gynecological Investigation 3 328-335

Dudley DJ, Edwin SS, Dangerfield A and Mitchell MD (1996b) Effect of interleukin 10 (IL-10) on prostaglandin $E_{2}$ production by fetal chorion and amnion cells Journal of the Society for Gynecological Investigation 3320A

Dudley D, Hunter C, Mitchell MD and Varner MW (1997a) Amniotic fluid interleukin 10 (IL-10) concentrations during pregnancy and with labour Journal of Reproductive Immunology 33 147-156

Dudley DJ, Edwin SS, Dangerfield A, Jackson K and Trautman MS (1997b) Regulation of decidual cell and chorion cell production of interleukin 10 by purified bacterial products American Journal of Reproductive Immunology 38 246-251

Economopoulos Pr Sun M, Purgina B and Gibb W (1996) Glucocorticoids stimulate prostaglandin $\mathrm{H}$ synthase type 2 (PGHS-2) in the fibroblast cells in human amnion cultures Molecular and Cellular Endocrinology 117 141-147

Fortunato SJ, Menon R, Swan K and Lombardi SJ (1996) Interleukin 10 inhibition of interleukin 6 in human amniochorion membrane: transcriptional regulation American Journal of Obstetrics and Gynecology 174 1057-1065

Fortunato SJ, Menon R and Lombardi SJ (1997) Interleukin 10 and transforming growth factor-beta inhibit amniochorion tumor necrosis factor-alpha production by contrasting mechanisms of action - therapeutic implications in prematurity American journal of Obstetrics and Gynecology 177 803-809

Fushimi T, Okayama H, Seiki T, Shimura S and Shiato K (1997) Dexamethasone suppressed gene expression and production of interleukin 10 by human peripheral blood mononuclear cells and monocytes International Archives of Allergy and Immunology 112 13-18

Gibb W and Breton R (1993) Studies on the action of dexamethasone on prostaglandin production by freshly dispersed amnion cells Acta Endocrinologica 128 563-567

Gomez R, Romero R, Edwin SS and David C (1997) Pathogenesis of preterm labour and preterm premature rupture of membranes associated with intraamniotic infection Infectious Disease Clinics of North America 11 135-176

Goodwin VJ, Sato T, Mitchell MD and Keelan JA (1998) Anti-inflammatory effects of interleukin 4 (IL-4), IL-10 and transforming growth factor $\beta$ on human placental cells in vitro. American Journal of Reproductive Immunology 40(5) 319-325

Grieg PC, Herbert WNP, Robinette BL and Teot LA (1995) Amniotic fluid interleukin 10 concentrations increase through pregnancy and are elevated in patients with preterm labour associated with intrauterine infection American Journal of Obstetrics and Gynecology 173 1223-1227

Halgunset J, Johnsen H, Kjollesdal AM, Qvigstad E, Espevik T and Austgulen R (1994) Cytokine levels in amniotic fluid and inflammatory changes in the placenta from normal deliveries at term European Journal of Obstetrics and Gynecology and Reproductive Biology 56 153-160

Heyborne K, McGregor JA, Henry G, Witkin SS and Abrams JA (1994) Interleukin 10 in amniotic fluid at midtrimester: immune activation and suppression in relation to fetal growth American Journal of Obstetrics and Gynecology 171 55-59

Hillier SL, Witkin SS, Krohn MA, Watts DH, Kiviat NB and Eschenbach DA (1990) The relationship of amniotic fluid cytokines and preterm delivery, amniotic fluid infection, histologic chorioamnionitis, and chorioamnion infection Obstetrics and Gynecology 81 941-948

Howard M and O'Garra A (1992) Biological properties of interleukin 10 Immunology Today 13 198-200

Jones CA, Finlay-Jones JJ and Hart PH (1997) Type 1 and Type 2 cytokines in human late-gestation decidual tissue Biology of Reproduction 57 303-311

Keelan JA, Sato T and Mitchell MD (1997) Interleukin (IL)-6 and IL-8 production by human amnion: regulation by cytokines, growth factors, glucocorticoids, phorbol esters, and bacterial lipopolysaccharide Biology of Reproduction 77 1438-1444

Kelly R (1994) Pregnancy maintenance and parturition: the role of prostaglandin in manipulating the immune and inflammatory response Endocrine Reviews 15 684-706

Kent ASH, Sullivan MHF and Elder (1994) Transfer of cytokines through human fetal membranes Journal of Reproduction and Fertility 100 81-84

Laham N, Rice GE, Bishop GJ, Ransome C and Brennecke SP (1993) Interleukin 8 concentrations in amniotic fluid and peripheral venous plasma during human pregnancy and parturition Acta Endocrinologica 129 220-224

Laham N, Brennecke SP, Bendtzen K and Rice GE (1996) Differential release of interleukin 6 from human gestational tissues in association with labour and in vitro endotoxin treatment Journal of Endocrinology 149 431-439

Lopez Bernal A, Hansell DJ, Alexander S and Turnbull AC (1987) Prostaglandin E production by amniotic cells in relation to term and preterm labour British Journal of Obstetrics and Gynecology 94 864-869

Lundin-Shiller S and Mitchell MD (1991) Prostaglandin production by human chorion laeve cells in response to inflammatory mediators Placenta 12 353-363

Mitchell MD, Lytton FD and Vanticovski L (1988) Paradoxical stimulation of both lipocortin and prostaglandin production in human amnion cells by dexamethasone Biochemical and Biophysical Research Communications 151 137-141 
Mitchell MD, Dudley DJ, Edwin SS, and Lundin-Schiller S. (1991) Interleukin 6 stimulates prostaglandin production by human amnion and decidual cells European Journal of Pharmacology 192 189-191

Mitchell MD, Romero R, Edwin SS and Trautman MS (1995) Prostaglandins and parturition Reproduction, Fertility and Development 7 623-632

Moore KW, O'Garra A, Malefyt DW, Viera P and Mosmann TR (1993) Interleukin 10 Annual Review of Immunology 11 165-190

Mosmann TR (1994) Properties and functions of interleukin 10 Advances in Immunology 56 1-26

Neki R, Matsuzaki N, Yamanaka K, Shimoya K, Okada T, Saji F, Iwashita M, Tanizawa $\mathbf{O}$ (1993) The interleukin 6 (IL-6) receptor system induces human chorionic gonadotrophin production by activating a tyrosine kinasedependent signal transduction pathway different from pathways triggered by protein kinase activators including gonadotropin releasing hormone journal of Clinical Endocrinology and Metabolism 77 704-709

Olson DM, Skinner K and Challis JR (1983) Prostaglandin output in relation to parturition by cells dispersed from human intrauterine tissues Journal of Clinical Endocrinology and Metabolism 57 694-699

Opsjon SL, Wathen NC, Tingulstad S, Wiedswang G, Sundan A, Waage A and Austgulen R (1993) Tumor necrosis factor, interleukin 1, and interleukin 6 in normal human pregnancy American Journal of Obstetrics and Gynecology 169 397-404

Paradowska E, Blacholszewska Z and Gejdel E (1997) Constitutive and induced cytokine production by human placenta and amniotic membrane at term Placenta $18441-446$

Perkins DJ and Kniss DA. (1997) Tumor necrosis factor alpha promotes sustained cyclooxygenase 2 expression: attenuation by dexamethasone and NSAIDs Prostaglandins 54 727-743

Petraglia F, Florio P, Nappi C and Genazzani AR (1996) Peptide signalling in human placenta and membranes: autocrine, paracrine, and endocrine mechanisms Endocrine Reviews 17 156-175

Pollard JK and Mitchell MD (1993) Tumor necrosis factor alpha stimulates amnion prostaglandin biosynthesis primarily via an action on fatty acid cyclooxygenase Prostaglandins 46 499-510

Potestio FA, Zakar T and Olson DM (1988) Glucocorticoids stimulate prostaglandin synthesis in human amnion cells by a receptor-mediated mechanism. Journal of Clinical Endocrinology and Metabolism 67 1205-1210

Romero R, Hobbins JC and Mitchell MD (1988) Endotoxin stimulates prostaglandin $\mathrm{E}_{2}$ production by human amnion Obstetrics and Gynecology 71 227-228

Romero R, Durum S, Dinarello CA, Oyarzun E, Hobbins JC and Mitchell
MD (1989) Interleukin 1 stimulates prostaglandin biosynthesis by human amnion Prostaglandins 37 13-22

Romero R, Ceska M, Avila C, Mazor M and Behnke E (1991) Neutrophil attractant/activating peptide 1 /interleukin 8 in term and preterm parturition American Journal of Obstetrics and Gynecology 165 813-820

Romero R, Mazor M, Brandt F, Sepulveda W, Avila C, Cotton DB and Dinarello CA (1992) Interleukin $1 \alpha$ and interleukin $1 \beta$ in preterm and term human parturition American Journal of Reproductive Immunology 27 117-123

Romero R, Baumann P, Gonzalez R, Gomez R, Rittenhouse L, Behnke E and Mitchell MD (1994) Amniotic fluid prostanoid concentrations increase early during the course of spontaneous labour at term American Joumal of Obstetrics and Gynecology 171 1613-1620

Romero R, Munoz H, Gomez R, Parra M, Polanco M, Valverde V, Hasbun J, Garrido J, Ghezzi F, Mazor M, Tolosa JE and Mitchell MD (1996) Increases in prostaglandin bioavailability precedes the onset of human parturition Prostaglandins, Leukotrienes and Essential Fatty Acids 54 187-191

Roth I, Corry DB, Locksley RM, Abrams JS, Litton MJ and Fisher SJ (1996) Human placental cytotrophoblasts produce the immunosuppressive cytokine interleukin 10 Journal of Experimental Medicine 184 539-548

Skinner KA and Challis JR (1985) Changes in the synthesis and metabolism of prostaglandins by human fetal membranes and decidua at labour American Journal of Obstetrics and Gynecology 151 519-523

Spencer S, Edwin S, Mitchell MD and Dudley DJ (1995) Interleukin 10 inhibits prostaglandin $\mathrm{E}_{2}\left(\mathrm{PGE}_{2}\right)$ and interleukin 6 production in human decidual cells: a potential role in preterm labour Journal of Investigative Medicine 43186

Stallmach T, Hebisch G, Joller-Jemelka, Orban P, Schwaller J and Engelmann M (1995) Cytokine production and visualised effects in the fetomaternal unit Laboratory Investigation 73 384-392

Stephanou A, Handwerger S (1994) Interleukin 6 stimulates placental lactogen expression by human trophoblast cells Endocrinology 135 719-723

Sun M, Ramirez M, Challis JRG and Gibb W (1996) Immunohistochemical localisation of the glucocorticoid receptor in human fetal membranes and decidua at term and preterm delivery Journal of Endocrinology 149 243-248

Trautman MS, Collmer D, Edwin SS, Mitchell MD and Dudley DJ (1996) Effect of interleukin 10 (IL-10) on IL-6 mRNA and cyclooxygenase II (COX0II) protein expression in human decidual cells Placenta 17 A47

Trautman MS, Collmer D, Edwin SS, White W, Mitchell MD and Dudley DJ (1997) Expression of interleukin 10 in human gestational tissues Journal of the Society for Gynecological Investigation 4 247-253 